\title{
Real-Time PCR Method for Detection of Zygomycetes ${ }^{\nabla}$
}

\author{
D. Jane Hata, $\uparrow$ Seanne P. Buckwalter, Bobbi S. Pritt, Glenn D. Roberts, and Nancy L. Wengenack* \\ Division of Clinical Microbiology, Mayo Clinic, Rochester, Minnesota 55905
}

Received 4 December 2007/Returned for modification 22 January 2008/Accepted 4 May 2008

\begin{abstract}
Zygomycete infections can be devastating in immunocompromised hosts. Difficulties in the histopathologic differentiation of this class from other filamentous fungi (e.g., Aspergillus spp., Fusarium spp.) may lead to delays in diagnosis and initiation of appropriate treatment, thereby significantly affecting patient outcome. A real-time PCR assay was developed to detect species of the zygomycete genera Absidia, Apophysomyces, Cunninghamella, Mucor, Rhizopus, and Saksenaea in culture and tissue samples. Primers and fluorescence resonance energy transfer hybridization probes were designed to detect a 167-bp conserved region of the multicopy zygomycete cytochrome $b$ gene. A plasmid containing target sequence from Mucor racemosus was constructed as a positive control. The analytical sensitivity of the assay is 10 targets/ $\mu \mathrm{l}$, and a specificity panel consisting of other filamentous fungi, yeasts (Candida spp.), and bacteria demonstrated no cross-reactivity in the assay. The clinical sensitivity and specificity of the assay from culture isolates were $100 \%(39 / 39)$ and 92\% (59/64), respectively. Sensitivity and specificity determined using a limited number of fresh tissue specimens were both $100 \%(2 / 2)$. The sensitivity seen with formalin-fixed, paraffin-embedded tissues was $56 \%(35 / 62)$, and the specificity was $100 \%(19 / 19)$. The speed, sensitivity, and specificity of the PCR assay indicate that it is useful for the rapid and accurate detection of zygomycetes.
\end{abstract}

Zygomycetes are common environmental fungi capable of producing serious disease in immunocompromised hosts. The vast majority of infections occur in individuals who are neutropenic, those receiving cytotoxic therapies, or those who have underlying metabolic acidosis. Although previously considered a relatively rare cause of disease, the incidence of opportunistic infections due to zygomycetes has increased over the last decade. Studies from multiple centers have indicated infection rates from $2.5 \%$ in bone marrow transplant recipients to $5.7 \%$ in solid-organ transplant recipients (10). Depending on the patient population, underlying disease, clinical presentation, and an early, accurate diagnosis, overall mortality rates due to zygomycete infections have ranged from $20 \%$ in localized infections to $100 \%$ in cases of disseminated disease $(5,13)$.

Members of the order Mucorales include species of the genera Rhizopus, Absidia, Mucor, Rhizomucor, Apophysomyces, Cunninghamella, and Saksenaea, and all have been implicated in human disease. Approximately $90 \%$ of all infections are caused by members of the genus Rhizopus, most commonly, $R$. arrhizus, followed by $R$. microsporus var. rhizopodiformis.

Currently, a diagnosis of zygomycosis is based upon identification of broad, ribbon-like, pauciseptate hyphae by histopathology or the use of macroscopic and microscopic morphology analysis following fungal culture. Histopathology determinations suffer from subjectivity that is dependent upon the experience of the reader. In addition, tissue processing, fixation, and staining may require several days, especially when the specimen is large and requires extended formalin fixation or

\footnotetext{
* Corresponding author. Mailing address: Division of Clinical Microbiology, Mayo Clinic, 200 1st St. SW, Rochester, MN 55905. Phone: (507) 284-3021. Fax: (507) 284-9859. E-mail: wengenack.nancy@mayo .edu.

† Present address: Mayo Clinic, Jacksonville, FL.

$\checkmark$ Published ahead of print on 14 May 2008.
}

when fungal stains are not initially ordered. When culture is used, the distinctive hyphal elements of zygomycetes may be difficult to distinguish visually from those of other filamentous fungi, especially during the early growth period. Although the zygomycetes grow quite rapidly on solid media, sporulation and identification may still take several days. In addition, when a zygomycetous infection is not specifically suspected at the time of specimen submission, tissues may undergo extensive processing (e.g., grinding) prior to culture, which ruptures the pauciseptate hyphae. It is therefore not unusual to have negative fungal culture results when histopathology results suggest the presence of zygomycete infection.

Molecular detection of zygomycetes has been infrequently reported in the literature. Imhof et al. developed a real-time PCR assay that detected, among other fungi, a single Conidiobolus isolate in culture (11). Recently, Schwarz et al. reported the molecular identification of zygomycetes in culture and experimentally infected mouse tissue by use of PCR followed by sequencing of the target amplicon (19).

We have developed a real-time PCR assay for the detection of zygomycetes in culture and tissue specimens (fresh and fixed). The assay targets a region of the multicopy cytochrome $b$ gene that is found in Absidia, Apophysomyces, Cunninghamella, Mucor, Rhizopus, and Saksenaea spp. Genus-level identification of members of these six zygomycete genera can be achieved in approximately $4 \mathrm{~h}$, providing essential and timely information to guide appropriate therapy. The specificity of PCR assay is such that the presence of other filamentous fungi (e.g., Aspergillus spp., Fusarium spp.), yeasts (Candida spp.), and bacteria may be excluded. The closed-system format of real-time PCR reduces the potential for contamination from environmental zygomycetes.

(This study was presented in part at the 104th General Meeting of the American Society for Microbiology, New Orleans, LA, 23 to 27 May 2004.) 
TABLE 1. Zygomycete culture isolates evaluated with LightCycler $\operatorname{PCR}(n=44)$

\begin{tabular}{|c|c|c|}
\hline Organism & $\begin{array}{l}\text { Accession no. } \\
\text { or source }\end{array}$ & $\begin{array}{l}\text { No. of } \\
\text { isolates }\end{array}$ \\
\hline Absidia coerulea & DSMZ 3018 & 1 \\
\hline Absidia corymbifera & DSMZ 1144 & 1 \\
\hline Absidia glauca & DSMZ 63295 & 1 \\
\hline Absidia repens & ATCC 14849 & 1 \\
\hline Absidia repens & DSMZ 812 & 1 \\
\hline Absidia $\mathrm{sp}$ & Clinical isolate & 1 \\
\hline Apophysomyces elegans & ATCC 64704 & 1 \\
\hline Apophysomyces elegans & ATCC 64705 & 1 \\
\hline Apophysomyces elegans & ATCC 46557 & 1 \\
\hline Apophysomyces sp. & Clinical isolate & 1 \\
\hline Conidiobolus coronatus & ATCC 32801 & 1 \\
\hline Cunninghamella bertholletiae & ATCC 42115 & 1 \\
\hline Cunninghamella blakesleeana & DSMZ 1906 & 1 \\
\hline Cunninghamella echinulata & DSMZ 1905 & 1 \\
\hline Cunninghamella elegans & DSMZ 1908 & 1 \\
\hline Cunninghamella sp. & Clinical isolate & 1 \\
\hline Mucor circinelloides & DSMZ 2183 & 1 \\
\hline Mucor flavus & DSMZ 2184 & 1 \\
\hline Mucor hiemalis & DSMZ 2656 & 1 \\
\hline Mucor mucedo & DSMZ 809 & 1 \\
\hline Mucor racemosus & DSMZ 62760 & 1 \\
\hline Mucor sp. & Clinical isolate & 6 \\
\hline Rhizomucor miehei & ATCC 22064 & 1 \\
\hline Rhizomucor miehei & DSMZ 1330 & 1 \\
\hline Rhizomucor pusillus & DSMZ 1331 & 1 \\
\hline Rhizopus microsporus var. chinensis & DSMZ 1834 & 1 \\
\hline Rhizopus microsporus var. chinensis & DSMZ 2195 & 1 \\
\hline Rhizopus microsporus var. oligosporus & DSMZ 1964 & 1 \\
\hline Rhizopus oryzae & DSMZ 5772 & 1 \\
\hline Rhizopus oryzae & DSMZ 853 & 1 \\
\hline Rhizopus oryzae & DSMZ 905 & 1 \\
\hline Rhizopus sp. & Clinical isolate & 3 \\
\hline Rhizopus stolonifer & ATCC 12938 & 1 \\
\hline Rhizopus stolonifer & DSMZ 2194 & 1 \\
\hline Rhizopus stolonifer & DSMZ 63011 & 1 \\
\hline Saksenaea vasiformis & ATCC 44101 & 1 \\
\hline Syncephalastrum racemosum & DSMZ 859 & 1 \\
\hline
\end{tabular}

\section{MATERIALS AND METHODS}

Culture isolates. Thirty-two isolates of zygomycetes belonging to the genera Absidia, Apophysomyces, Conidiobolus, Cunninghamella, Mucor, Rhizopus, Rhizomucor, Saksenaea, and Syncephalastrum were obtained from the American Type Culture Collection (ATCC) or from Deutsche Sammlung von Mikroorganismen und Zellkulturen GmbH (DSMZ). An additional 12 zygomycete isolates were obtained from clinical specimens submitted to the Mayo Clinic Mycology Laboratory during the period 2003 to 2004. All zygomycete stock isolates were cultured on inhibitory mold agar plates and incubated at $30^{\circ} \mathrm{C}$ until hyphal growth was observed. The identity of stock isolates was confirmed on the basis of microscopic morphology (Table 1). Fungal cultures were lysed using PrepMan Ultra reagent (Applied BioSystems, Foster City, CA) following the method of Hall et al. (7). DNA was extracted using a MagNA Pure platform (Roche Applied Sciences, Indianapolis, IN), a total nucleic acid isolation kit, and a final elution volume of $100 \mu \mathrm{l}$.

Formalin-fixed tissue. A review of archived pathology specimens from the Mayo Clinic in Rochester collected from 1995 to 2004 revealed nine cases with diagnoses consistent with zygomycete infection, as determined by pathologist interpretations of fungal morphology and staining characteristics. From the nine cases with positive results, a total of 81 formalin-fixed, paraffin-embedded tissue blocks were available for evaluation. All slides from the cases were subsequently reviewed by an independent pathologist (B.S.P.) to confirm the initial histopathologic diagnosis.

One 50- $\mu \mathrm{m}$-thick section from each block was obtained using a microtome and placed into a 1.5 -ml screw-top tube. Tissue lysates were prepared by washing the tissue sections with xylene to remove wax followed by washing with $95 \%$ alcohol. The tissues were then placed in a mixture of $500 \mu \mathrm{l}$ of Tris-EDTA buffer, $50 \mu \mathrm{l}$ of $10 \%$ sodium dodecyl sulfate, and $100 \mu \mathrm{l}$ of proteinase $\mathrm{K}$. The tissues were incubated for $24 \mathrm{~h}$ at $55^{\circ} \mathrm{C}$ by use of a Thermomixer (Eppendorf AG, Hamburg Germany) at $500 \mathrm{rpm}$. Fresh tissue specimens were also obtained prospectively from specimens submitted to the Mayo Clinic Surgical Pathology service. They were placed directly in the Tris-EDTA-sodium dodecyl sulfate-proteinase $\mathrm{K}$ mixture without the xylene-alcohol step.

Primer and probe design. The cytochrome $b$ gene is a highly conserved, multicopy gene which has exhibited utility in the classification, identification, and phylogenetic analysis of yeasts and filamentous fungi $(23,25)$. The National Center for Biotechnology Information website (http://www.ncbi.nlm.nih.gov) was searched using the keywords "zygomycete" and "cytochrome $b$ " to identify available cytochrome $b$ sequences in the zygomycete class. Data for fluorescence resonance energy transfer (FRET) probe construction were also supplemented by sequence analysis of PCR products from culture-confirmed zygomycete isolates from the Mayo Clinic. The sequences were further examined using OligoPrimer analysis v. 6.61 software (Molecular Biology Insights, Inc.), BioEdit sequence alignment editor v. 7.0 software (Isis Pharmaceuticals, Inc.), and Sequencher v. 4.0.5 software (Gene Codes, Inc., Ann Arbor, MI) to identify suitable regions for primer and hybridization probes based on sequence homologies among six genera (Rhizopus, Absidia, Mucor, Apophysomyces, Cunninghamella, and Saksenaea). Forward (5'-TAGGAATTACAGCAAAT-3') and reverse (5'-CCA ATGCAAACTCC-3') oligonucleotide primers were designed to amplify a specific 167-bp region of the cytochrome $b$ gene. FRET hybridization probes were composed of the following sequences: $5^{\prime}$-ACAATTTTCTTATTCTTCTTAGT ATTAG-3' (anchor probe) ( $3^{\prime}$ fluorescein labeled) and 5'-TTTATTCTTATTC TATGCTCCAAATA-3' (donor probe) (5' LCRED-640 labeled). Primers and probes were synthesized by TIB Molbiol (Berlin, Germany).

Positive-control plasmid. Using the primers described above, a plasmid containing a 167-bp region of the Mucor racemosus (accession no. DSMZ 62760) cytochrome $b$ consensus sequence was constructed using a pCR 2.1 TOPO TA cloning kit (Invitrogen Corp., Carlsbad, CA). Mucor racemosus was selected for the positive control because it had the most complete sequence data available via GenBank and supplemental sequence analysis. Briefly, nucleic acid from $M$. racemosus was extracted as described by Hall et al. by use of a Roche MagNA Pure kit and a total nucleic acid isolation kit (Roche Applied Sciences, Indianapolis, IN) (6). Purified nucleic acid was subjected to PCR using the primers described above and targeting a 167-bp region of the cytochrome $b$ gene. The PCR product was then ligated into the PCR 2.1 vector by use of a TOPO TA cloning kit, following the instructions of the manufacturer. The expected size of the recombinant plasmid was confirmed with $2 \%$ agarose gel electrophoresis, and the reaction mixture was purified using a Roche High Pure plasmid isolation kit (Roche Applied Science, Indianapolis, IN). The positive-control plasmid was diluted into Tris-EDTA buffer ( $\mathrm{pH} 8.0)$ and stored at $4^{\circ} \mathrm{C}$.

LightCycler PCR. Real-time PCR amplification and amplicon detection using extracted DNA template was performed with using a Roche LightCycler system. Each reaction mixture contained $15 \mu \mathrm{l}$ of the PCR master mix plus $5 \mu \mathrm{l}$ of the extracted DNA from clinical specimens or control material. The PCR mixture consisted of $1 \times$ LightCycler FastStart DNA master hybridization probe buffer, 3 $\mathrm{mM} \mathrm{MgCl}_{2}, 0.5 \mu \mathrm{M}$ forward and reverse primers, $0.2 \mu \mathrm{M}$ fluorescein-labeled probe, and $0.4 \mu \mathrm{M}$ RED 640-labeled probe. The total volume per reaction mixture was $20 \mu \mathrm{l}(15 \mu \mathrm{l}$ of master mix plus $5 \mu \mathrm{l}$ of sample). Amplification conditions consisted of 1 cycle of $95^{\circ} \mathrm{C}$ for $10 \mathrm{~min}$ followed by 45 cycles of $95^{\circ} \mathrm{C}$ for $10 \mathrm{~s}$ (denaturation), $48^{\circ} \mathrm{C}$ for $15 \mathrm{~s}$ (annealing), and $72^{\circ} \mathrm{C}$ for $15 \mathrm{~s}$ (extension). A melting curve was generated using the following profile: $95^{\circ} \mathrm{C}$ for $0 \mathrm{~s}, 59^{\circ} \mathrm{C}$ for $20 \mathrm{~s}$, and $34^{\circ} \mathrm{C}$ for $20 \mathrm{~s}$, with a $0.3^{\circ} \mathrm{C} / \mathrm{sec}$ transition, and $85^{\circ} \mathrm{C}$ for $0 \mathrm{sec}$, with a $0.3^{\circ} \mathrm{C} / \mathrm{s}$ transition. Analysis was performed using a LightCycler v. 1.2 system with LightCycler v. 3.5 software.

Analytical sensitivity and specificity. Dilutions of the plasmid control were prepared to assess the analytical sensitivity of the PCR assay. A range of 5 to 500,000 copies of target DNA per reaction were tested in triplicate. The sensitivity of the PCR assay from culture was tested using DNA extracted as described above and 32 zygomycete stock isolates and 12 confirmed clinical zygomycete isolates (Table 1). The analytical specificity of the assay was determined by performing a BLAST search of the primer and probe sequences on the National Center for Biotechnology Information website (http://www.ncbi.nlm.nih.gov). Further, a specificity panel containing DNA extracted from clinical isolates of yeast, filamentous fungi, and bacteria was tested for potentially cross-reacting organisms (Table 2). Amplification and sequencing of 16S (bacteria) and D2 large ribosomal subunit (fungi) or specific PCR assays were utilized to confirm the presence of amplifiable nucleic acid in the specificity panel and organism identification $(6,7)$.

Accuracy. Sections from formalin-fixed, paraffin-embedded tissue blocks that were either positive or negative for zygomycetes by histopathology were also 
TABLE 2. Specificity panel of isolates tested for cross-reactivity using a Zygomycete LightCycler PCR assay

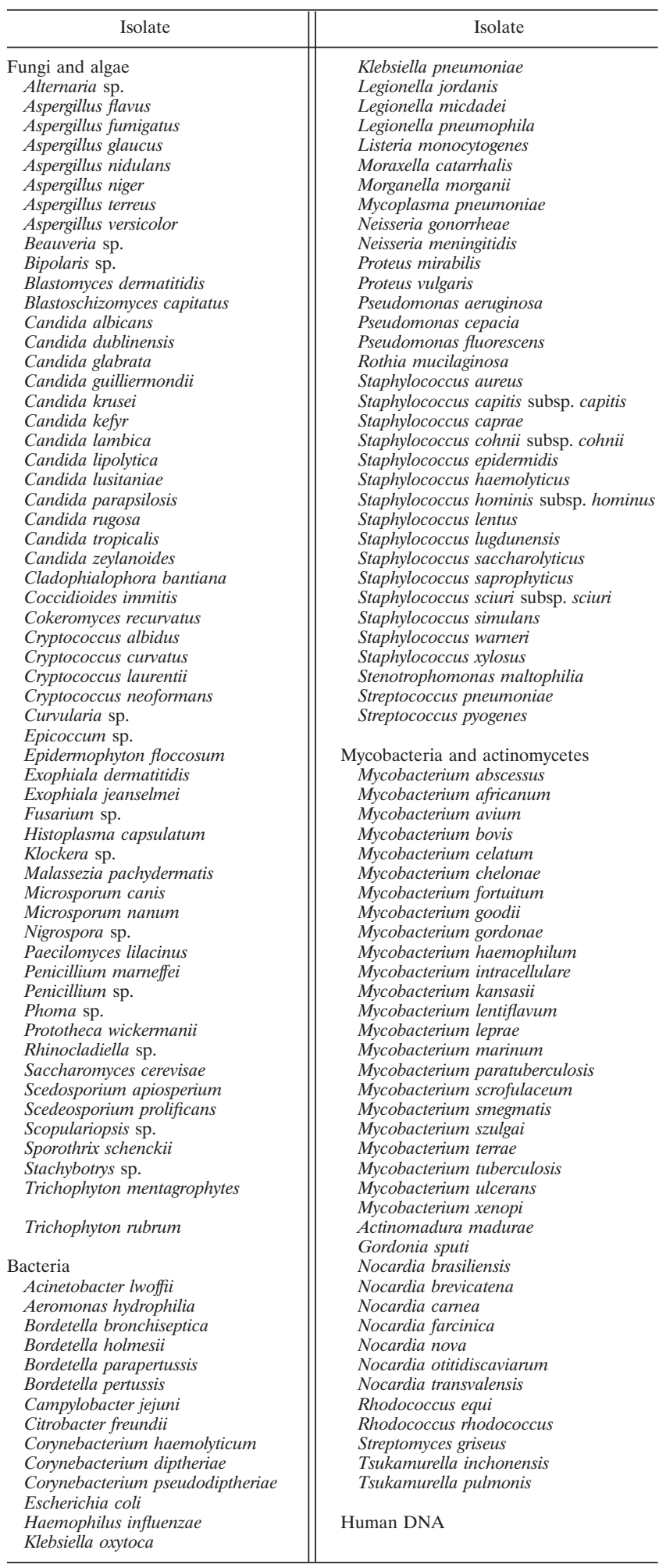

were evaluated using the PCR method. A specimen was considered to be histopathology positive when the pathology report and independent pathology review indicated the presence of fungal elements consistent with the presence of a zygomycete.
Inhibition studies. Extraction inhibition and PCR inhibition were assessed by spiking tissue lysates not containing zygomycetes with known concentrations of the plasmid control prior to and after DNA extraction. Plasmid concentrations used were within $1 \mathrm{log}$ of the limit of sensitivity of the assay.

\section{RESULTS}

Analytical sensitivity and specificity. The analytical sensitivity was determined to be 10 targets/ $\mu$ l (50 targets/reaction) by use of the plasmid control. Melt curve analysis demonstrated an average melting temperature of $49.3^{\circ} \mathrm{C} \pm 0.16^{\circ} \mathrm{C}$ (mean \pm standard deviation) for the plasmid control (Fig. 1). The assay did not demonstrate cross-reactivity with any of the organisms included in the specificity panel (Table 2).

Clinical sensitivity and specificity. A total of 44 zygomycete culture isolates were tested using a LightCycler PCR assay (Table 1 and Table 3). Thirty-nine of 44 culture isolates were detected in the assay. All specimens belonging to the genera Rhizopus, Mucor, Absidia, Cunninghamella, Apophysomyces, and Saksenaea were detected with the PCR assay. As expected, isolates of Rhizomucor $(n=3)$, Condiobolus $(n=1)$, and Syncephalastrum $(n=1)$ spp. were not detected by the assay since the selected probes were not specific for these organisms. The six genera exhibited a range of melt temperatures from $41^{\circ} \mathrm{C}$ to $55^{\circ} \mathrm{C}$, with three genera (Absidia, Aphophysomyces, and Mucor) having melt temperatures within approximately $1^{\circ} \mathrm{C}$ of each other (Fig. 1). DNA isolated from fifty-nine cultures growing nonzygomycetous fungi (Table 2) was also tested. All results were negative using the PCR assay, corresponding to an assay specificity of $100 \%$.

Eighty-one formalin-fixed, paraffin-embedded tissue samples from nine patients were tested with the LightCycler PCR assay. Thirty-five tissue samples were positive by both LightCycler PCR and histopathology, while 19 specimens were negative by both techniques. Twenty-seven specimens were positive by histopathology but negative by the PCR assay, resulting in a sensitivity of $56.5 \%$ (Table 3 ).

Two fresh sinus cavity tissue samples from a patient with positive histopathology results were available for analysis. DNA isolated from two of two fresh tissue samples were positive with the PCR assay, and fungal culture samples from the samples were positive for Apophysomyces elegans.

Inhibition study. To assess potential extraction inhibition and PCR inhibition by use of formalin-fixed, paraffin-embedded tissues, digested samples from tissue not containing zygomycetes were spiked in triplicate with known concentrations of the plasmid control prior to automated nucleic acid extraction. No inhibition was observed in the spiked tissue specimens, despite a drop in fluorescence intensity of the melting peaks. In a separate PCR inhibition experiment, when a positive plasmid control was added to negative tissue extracts after MagNA Pure extraction, there was again no inhibition observed.

\section{DISCUSSION}

It has been estimated that the incidence of zygomycete infections is relatively low, but they nevertheless constitute a significant area of concern, especially in immunosuppressed patient populations. Although overall survival rates in cases of zygomycosis have increased from $50 \%$ to $80 \%$ over the last 10 years (5), the overall incidence rate has shown a disturbing 


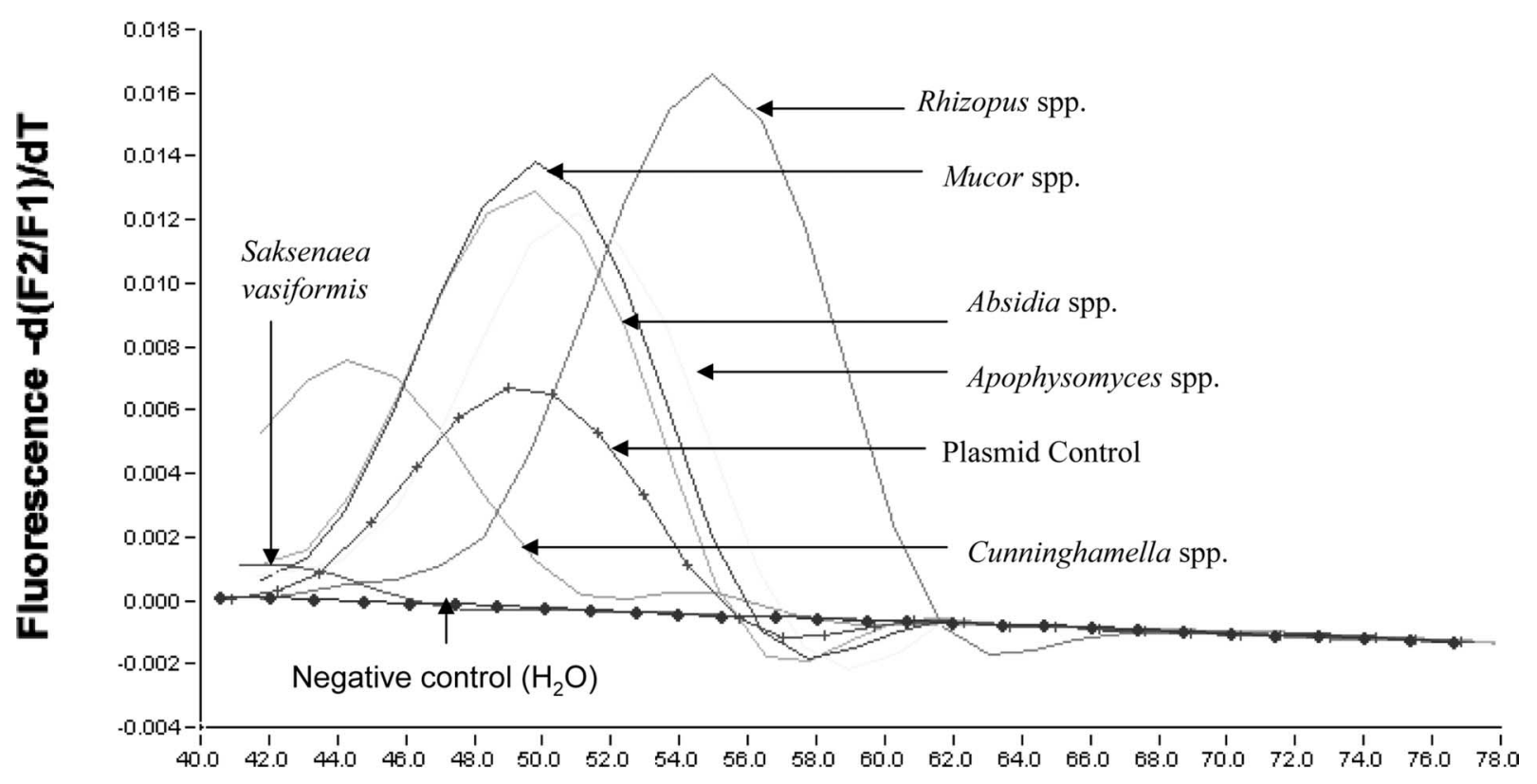

Temperature ( $\left.{ }^{\circ} \mathrm{C}\right)$

FIG. 1. Melt curves for the zygomycete genera detected by the LightCycler PCR assay. Average melting-temperature values were as follows: for Absidia spp., $49.9^{\circ} \mathrm{C}$; for Apophysomyces spp., $51.0^{\circ} \mathrm{C}$; for Cunninghamella spp., $44.3^{\circ} \mathrm{C}$; for Mucor spp., $49.9^{\circ} \mathrm{C}$; for Rhizopus spp., $55.0^{\circ} \mathrm{C}$; and for Saksenaea vasiformis, $41.9^{\circ} \mathrm{C}$.

upward trend (13). Delays in accurate identification of zygomycete infections negatively affect patient survival. In a retrospective series from a single institution, premortem diagnosis of zygomycosis was performed with only $22 \%$ of cases prior to 1970 and with $93 \%$ of cases after 1970, and survival rates were $20 \%$ and $73 \%$, respectively (13). Inappropriate antifungal therapy, secondary to incomplete identification or misidentification of zygomycete infections, has clearly led to a reduction in survival rates $(5,24)$. Recent reports of a zygomycete "breakthrough" in treatment of patients on long-term prophylaxis with voriconazole presents an additional need for the accurate and rapid identification of these organisms $(16,21,22)$.

Diagnosis of zygomycosis may be made on the basis of morphological identification of characteristic hyphae present in tissue or other clinical specimens (5). However, extensive necrosis, hyphal fragmentation, and poor staining of the thin hyphal walls may make microscopic visualization difficult. Finally, a pathologist may mistakenly conclude that the presence of septations excludes the diagnosis of zygomycosis, since it

TABLE 3. Detection of zygomycetes in culture isolates and in fixed tissue

\begin{tabular}{|c|c|c|c|c|}
\hline \multirow[t]{2}{*}{$\begin{array}{l}\text { LightCycler } \\
\text { PCR result }\end{array}$} & \multicolumn{2}{|c|}{$\begin{array}{l}\text { No. of culture isolates } \\
\text { with indicated result }\end{array}$} & \multicolumn{2}{|c|}{$\begin{array}{l}\text { No. of isolates with } \\
\text { indicated result by } \\
\text { histopathology of } \\
\text { fixed tissue }\end{array}$} \\
\hline & Positive & Negative & Positive & Negative \\
\hline Positive & 39 & 0 & 35 & 0 \\
\hline Negative & $5^{a}$ & 59 & 27 & 19 \\
\hline
\end{tabular}

${ }^{a}$ Cultures grew species of Rhizomucor $(n=3)$, Syncephalastrum $(n=1)$, and Conidiobolus $(n=1)$, which are genera not detected by this PCR assay. was previously thought that zygomyce hyphae are aseptate instead of pauciseptate (4).

Fungal culture is necessary for genus identification, because histopathologic diagnosis can be difficult. However, the recovery of zygomycetes in culture can be a difficult proposition. Blood and urine culture results are rarely positive in the diagnosis of zygomycosis (5). Tissue samples may undergo aggressive initial processing, thereby making hyphal elements nonviable. In one study, $33 \%$ of histologically proven zygomycete infections failed to grow in culture (13). In addition, fungal hyphae may be present in only a portion of the specimen, again resulting in poor recovery for culture (18). Although zygomycetes are commonly found in the environment, recovery from cultures from sterile sites should never be dismissed as laboratory contamination but should be considered to represent a medical emergency in cases involving immunocompromised patients (5). However, their presence in nonsterile sites requires accurate clinical correlation.

Molecular methods are potentially helpful for the detection and identification of zygomycetes. Methods such as in situ hybridization (8), conventional PCR $(1,3,12,14,15,17)$ and nucleic acid sequencing $(9,19)$ have been reported, but all suffer from a relatively long turnaround time compared to the time required for the clinical progression of a zygomycete infection. The application of real-time PCR methodologies is especially attractive as a choice for clinical diagnostics due to increases in detection sensitivity, reduction of outside contamination, and decreased test turnaround time.

We have developed a real-time PCR assay using the LightCycler platform that is highly specific for species of six clinically significant zygomycetes genera (Rhizopus, Mucor, Absidia, 
Apophysomyces, Cunninghamella, and Saksenaea). These species comprise the majority of isolates noted in our clinical practice. The PCR is highly sensitive and detects as few as 10 copies of the zygomycete cytochrome $b$ gene in samples from culture isolates. The overlapping melt curves obtained with Absidia, Apophysomyces, and Mucor spp. prevent identification to the genus level using the assay; however, initiation of appropriate therapy does not depend on specific identification to this level. Although it is highly conserved compared with other zygomycete targets considered, there was enough variation with the cytochrome $b$ target region that the construction of a single set of FRET hybridization probes that detected all genera of zygomycetes is impractical. Therefore, Rhizomucor, Conidiobolus, and Syncephalastrum spp. are not detected with this PCR assay. Although these species are not commonly seen in our clinical practice, future design of additional FRET probes may allow for detection of these genera.

The performance of the PCR assay using samples from culture and a limited number of organisms in fresh tissue was excellent, with $100 \%$ sensitivity and no cross-reactivity demonstrated with the tested species of other filamentous fungi, yeasts, or bacteria. Sensitivity of the assay using samples from formalin-fixed, paraffin-embedded tissue was lower at $57 \%$. Several factors may contribute to reduced sensitivity in fixed tissue. It is possible that subjectivity associated with the histopathology interpretation may have contributed to decreased sensitivity. More likely, extensive cross-linking of tissue proteins after fixation in formaldehyde may have resulted in nucleic acid fragmentation and inhibition of the PCR process (2). Although our intentional use of a short (167-bp) amplicon as the target somewhat mitigated this effect, DNA fragmentation may still have contributed to lower sensitivity with fixed tissue. Interestingly, for a single patient with invasive zygomycosis due to $A$. elegans, fixed frontal sinus tissue was PCR assay negative, whereas fresh tissue was PCR positive. Finally, the success of recovery of organism DNA might vary due to sampling issues associated with the use of discrete tissue sections from each tissue block rather than use of the entire specimen, as can often be done with fresh specimens.

The greatest advantage for the use of real-time PCR in the diagnosis of zygomycete infection is the reduction of turnaround time for results from days to hours, a difference that can have a significant positive impact on patient care. The growth of zygomycetes in culture is often quite brisk, causing many mycologists to refer to these organisms as "lid-lifters" in reference to their ability to rapidly escape the confines of an agar plate within a few hours. While identification of zygomycetes after growth in culture by use of microscopic morphology can be relatively simple at times, there are instances in which the identification is unclear due to poor sporulation or an inexperienced reader. The PCR assay described herein can be utilized to provide an objective result either as a stand-alone test or as a complement to microscopy. In instances in which no culture assay is performed, the ability to perform a rapid identification using samples of fixed tissue is vital to patient management. Tissue fixation, processing, and histopathology examination of biopsy specimens may take several days. The combination of automated DNA extraction with real-time PCR significantly reduces turnaround time to 2 to $4 \mathrm{~h}$. In addition, the lack of cross-reactivity demonstrated by the PCR assay may make it extremely useful in excluding infections due to fungi other than zygomycetes, thereby reducing the risk of inappropriate empirical therapy. Incorporation of this assay into the normal laboratory workflow is quite practical, as exemplified by other molecular tests performed in our laboratory (20). Further studies are required to determine the utility of this test in the detection of zygomycetes in samples from other specimen types.

\section{ACKNOWLEDGMENTS}

We thank Leslie Hall for expert technical assistance and advice with this study. We also acknowledge the laboratory technologists and assistants in the Mycology Laboratory at the Mayo Clinic, Rochester, $\mathrm{MN}$, for their assistance with this study.

\section{REFERENCES}

1. Bialek, R., F. Konrad, J. Kern, C. Aepinus, L. Cecenas, G. M. Gonzalez, G. Just-Nübling, B. Willinger, E. Presterl, C. Lass-Flörl, and V. Rickerts. 2005. PCR based identification and discrimination of agents of mucromycosis and aspergillosis in paraffin wax embedded tissue. J. Clin. Pathol. 58:1180-1184.

2. Bonin, S., F. Petera, B. Niccolini, and G. Stanta. 2003. PCR analysis in archival postmortem tissues. Mol. Pathol. 56:184-186.

3. Einsele, H., H. Hebart, G. Roller, J. Löffler, I. Rothenhöfer, C. A. Müller, R. A. Bowden, J. van Burik, D. Englehard, L. Kanz, and U. Schumacher. 1997. Detection and identification of fungal pathogens in blood by using molecular probes. J. Clin. Microbiol. 35:1353-1360.

4. Frater, J. L., G. S. Hall, and G. W. Procop. 2001. Histologic features of zygomycosis. Arch. Pathol. Lab. Med. 125:375-378.

5. Gonzalez, C. E., M. G. Rinaldi, and A. M. Sugar. 2002. Zygomycosis. Infect. Dis. Clin. N. Am. 16:895-914.

6. Hall, L., K. A. Doerr, S. L. Wohlfiel, and G. D. Roberts. 2003. Evaluation of the MicroSeq system for identification of mycobacteria by $16 \mathrm{~S}$ ribosomal DNA sequencing and its integration into a routine clinical mycobacteriology laboratory. J. Clin. Microbiol. 41:1447-1453.

7. Hall, L., S. Wohlfiel, and G. D. Roberts. 2004. Experience with the MicroSeq D2 large-subunit ribosomal DNA sequencing kit for identification of filamentous fungi encountered in the clinical laboratory. J. Clin. Microbiol. 42:622-626.

8. Hayden, R. T., X. Qian, G. W. Procop, G. D. Roberts, and R. V. Lloyd. 2001 In situ hybridization for the identification of yeastlike organisms in tissue section. Diagn. Mol. Pathol. 10:15-23.

9. Hendolin, P. H., L. Paulin, P. Koukila-Kähköl, V. Anttila, H. Malmberg, M. Richardson, and J. Ylikoski. 2000. Panfungal PCR and multiplex liquid hybridization for detection of fungi in tissue specimens. J. Clin. Microbiol. 38:4186-4192.

10. Husain, S., B. D. Alexander, P. Munoz, R. K. Avery, S. Houston, T. Pruett, E. A. Jacobs, E. A. Dominguez, J. G. Tollemar, K. Baumgarten, C. M. Yu, M. M. Wagener, P. Linden, S. Kusne, and N. Singh. 2003. Opportunistic mycelial fungal infections in organ transplant recipients: emerging importance of non-Aspergillus mycelial fungi. Clin. Infect. Dis. 37:221-229.

11. Imhoff, A., C. Schaer, G. Schoedon, D. J. Schaer, R. B. Walter, A. Schaffner, and M. Schneemann. 2003. Rapid detection of pathogenic fungi from clinical specimens using LightCycler real-time fluorescence PCR. Eur. J. Clin. Microbiol. Infect. Dis. 22:558-560.

12. Kappe, R., C. N. Okeke, C. Fauser, M. Maiwald, and H. G. Sonntag. 1998. Molecular probes for the detection of pathogenic fungi in the presence of human tissue. J. Med. Microbiol. 47:811-820.

13. Kontoyiannis, D. P., V. C. Wessel, G. P. Bodey, and K. V. Rolston. 2000. Zygomycosis in the 1990 s in a tertiary-care cancer center. Clin. Infect. Dis. 30:851-856.

14. Larché, J., M. Machorart, K. Burton, J. Collomb, M. F. Biava, A. Gerard, and B. Fortier. 2005. Diagnosis of cutaneous mucormycosis due to Rhizopus microsporus by an innovative PCR-restriction fragment-length polymorphism method. Clin. Infect. Dis. 41:1362-1365.

15. Machouart, M., J. Larché, K. Burton, J. Collomb, P. Maurer, A. Cintrat, M. F. Biava, S. Greciano, A. F. A. Kuijpers, N. Contet-Audonneau, G. S. de Hoog, A. Gérard, and B. Fortier. 2006. Genetic identification of the small opportunistic murcorales by PCR-restriction fragment length polymorphism. J. Clin. Microbiol. 44:805-810.

16. Malani, A. N., and C. A. Kauffman. 2007. Changing epidemiology of rare mould infections: implications for therapy. Drugs 67:1803-1812.

17. Nagao, K., T. Ota, A. Tanikawa, T. Mori, S. Udagawa, and T. Nishikawa. 2005. Genetic identification and detection of human pathogenic Rhizopus species, a major mucormycosis agent, by multiplex PCR based on internal transcribed spacer region of rRNA gene. J. Dermatol. Sci. 39:23-31.

18. Ribes, J. A., C. L. Vanover-Sams, and D. J. Baker. 2000. Zygomycetes in human disease. Clin. Microbiol. Rev. 13:236-301. 
19. Schwarz, P., S. Bretagne, J. C. Gantier, D. Garia-Hermoso, O. Lortholary, F Dromer, and E. Dannaoui. 2006. Molecular identification of zygomycetes from culture and experimentally infected tissues. J. Clin. Microbiol. 44:340-349.

20. Sloan, L. M., M. K. Hopkins, P. S. Mitchell, E. A. Vetter, J. E. Rosenblatt, W. S. Harmsen, F. R. Cockerill, and R. Patel. 2002. Multiplex LightCycler PCR assay for detection and differentiation of Bordetella pertussis and Bordetella parapertussis in nasopharyngeal specimens. J. Clin. Microbiol. 40:96-100.

21. Trifilio, S., S. Singhal, S. Williams, O. Frankfurt, L. Gordon, A. Evens, J. Winter, M. Tallman, J. Pi, and J. Mehta. 2007. Breakthrough fungal infections after allogeneic hematopoietic stem cell transplantation in patients on prophylactic voriconazole. Bone Marrow Transplant. 40:451-456.

22. Trifilio, S. M., C. L. Bennett, P. R. Yarnold, J. M. McKoy, J. Parada, J. Mehta, G. Chamilos, F. Palella, L. Kennedy, K. Mullane, M. S. Tallman, A.
Evens, M. H. Scheetz, W. Blum, and D. P. Kontoyiannis. 2007. Breakthrough zygomycosis after voriconazole administration among patients with hematologic malignancies who receive hematopoietic stem-cell transplants or intensive chemotherapy. Bone Marrow Transplant. 39:425-429.

23. Wang, L., K. Yokoyama, M. Miyaji, and K. Nishimura. 1998. The identification and phylogenic relationship of pathogenic species of Aspergillus based on the mitochondrial cytochrome b gene. Med. Mycol. 36:153-164.

24. Yohai, R. A., J. D. Bullock, A. A. Aziz, and R. J. Market. 1994. Survival factors in rhino-orbital-cerebral mucormycosis. Surv. Ophthalmol. 39:3-22.

25. Yokoyama, K., S. K. Biswas, M. Miyaji, and K. Nishimura. 2000. Identification and phylogenetic relationship of the most common pathogenic Candida species inferred from mitochondrial cytochrome $\mathrm{b}$ gene sequences. J. Clin. Microbiol. 38:4503-4510. 